\title{
MISCELLANEA
}

\section{KRAMÁŘSKÉ TISKY JAKO PŘEDMĚT SBĚRATELSTVÍ ANEB CESTY KRAMÁŘSKÝCH PÍSNÍ DO MORAVSKÝCH MUZEÍ A KNIHOVEN}

\author{
Romana Macháčková (Brno)
}

\begin{abstract}
Chapbooks as a Collectable, or the Journeys of Chapbooks to Museums and Libraries in Moravia
Abstract: This article presents the journeys of the collections of chapbooks to museums and libraries in Moravia. The article attempts to outline the individual ways in which chapbooks came to particular institutions. It highlights acquisitions by purchase and donation. It also deals with the individuals behind the creation of the collections.
\end{abstract}

Keywords: chapbooks - museums in Moravia - libraries in Moravia - method of acquisition

Námět na tento článek vznikl v průběhu prací na projektu NAKI Kramářské písně v brněnských historických fondech, který je naplňován součinností Moravské zemské knihovny v Brně, brněnského pracoviště Etnologického ústavu AV ČR, v. v. i., a Etnografického ústavu Moravského zemského muzea. ${ }^{1}$

Terénní výzkum v moravských institucích probíhal v letech 2018-2019. Jednotlivá muzea, archivy i knihovny jsem navštívila osobně a sesbírala potřebné materiály, na jejichž podkladě mohl tento článek vzniknout. ${ }^{2}$ Výjimkou byl výzkum fondu kramářských písní v Moravské zemské knihovně v Brně, který jsem prováděla společně s kolegyní Mgr. Hanou Glombovou. Na základě našeho výzkumu vznikl konferenční příspěvek s názvem Kramářské tisky ve fondech Moravské zemské knihovny v Brně přednesený na mezinárodní konferenci Proměny české kramářské pisně - média, tradice, kontexty pořádané 11.-13. září 2019 v Brně, který popisuje danou sbírku zevrubně. Část věnující se proveniencím, datacím a především sběrům, dárcům a nákupům jsem zařadila do tohoto článku s laskavým svolením své, dnes již bývalé kolegyně.

Vybrané instituce jsou samozrrejmě pouhým zlomkem institucí na Moravě, které ve svých sbírkách kramářské písně vlastní. Cílem výzkumu však bylo postihnout reálný obraz z rozdílných geografických oblastí i z rozdílných typů institucí - at' už co se jejich velikosti týče, či jejich zaměření. Ve výsledcích prezentovaných v tomto př́spěvku nenabízím absolutně vyčerpávající soupisy ani si nečiním nárok na jedinou pravdu o tom, jakými způsoby se kramářské tisky at' už jednotliviny (drobné tisky, které si obyvatelé přinášeli domů nejen ze svých poutí), či špalíčky (většinou podomác$\mathrm{ku}$ vytvořené fascinující svazky s vazbami $\mathrm{z}$ různých materiálů a unikátní tím, že neexistují dva úplně stejné exempláře - jejich obsah vždy souvisel se zaměřením a vkusem vlastníka a tvưrce) do institucí dostávaly. Jednotlivé instituce je získávaly opravdu různými způsoby, což se odvíjelo od mnoha faktorů. Mnohdy jsou nabízené cesty dohledávání slepé. Anebo naopak otevírají možnosti k dalším, podrobnějším výzkumům, které však v rámci vzniku tohoto článku nebylo možné z časových a finančních důvodů realizovat.

Základní kladené otázky, které se v rámci výzkumu otevíraly, byly: O jak velkou sbírku se jedná?, Nakolik jsou v ní zastoupeny kramářské písně duchovní a nakolik naopak písně světské?, Z jakého období a odkud (místo tisku, případně jméno tiskaře) pocházejí?, $\mathrm{V}$ jakém jazyku jsou tištěné?, Jaký je poměr jednotlivin a špalíčků?, Jaká je jejich opotřebovanost (tedy častost používání jejich majitelem)?, Jak se do instituce dostaly - nákup, dar, jiný způsob nabytí?

\footnotetext{
${ }^{1}$ Př́íspěvek vznikl v rámci Institucionální podpory na dlouhodobý koncepční rozvoj výzkumné organizace - Moravská zemská knihovna v Brně.

2 Při tomto výzkumu bych samozřejmě nezjistila vůbec nic bez pomoci a skvělé spolupráce kolegů a kolegyñ z jednotlivých muzeí a knihoven. Chci poděkovat za pomoc, množství velmi př́nosných informací a samozřejmě za umožnění př́stupu do jednotlivých fondů a sbírek PhDr. Aleně Prudké z Muzea jihovýchodní Moravy ve Zlíně, Mgr. Martině Krajíčkové z Muzea ve Šlapanicích, Mgr. Martě Němečkové z Muzea v Ivančicích, Mgr. Jiřímu Glonkovi ze Studovny historických fondů ve Vědecké knihovně v Olomouci, Mgr. Bc. Petru Ecklovi z Jihomoravského muzea ve Znojmě, Petře Hubáčkové z Muzea a galerie v Prostějově, Mgr. Petru Číhalovi ze Slováckého muzea v Uherském Hradišti a Mgr. Heleně Kovářové z Muzea Komenského v Přerově.
} 
Zajímal mě i způsob uložení a způsob odborného zpracování jednotlivých sbírek. V následujících kapitolách se věnuji již podrobně jednotlivým institucím.

\section{Vědecká knihovna v Olomouci}

Ve Vědecké knihovně v Olomouci jsou kramářské písně uloženy v oddělení historických fondů. Vzhledem k faktu, že sbírka není příliš rozsáhlá, není překvapivé, že stojí na okraji zájmu knihovníků. Informace $\mathrm{k}$ příslušným kramářským písním jsem obdržela velmi kusé, $v$ průběhu mých návštěv byly některé položky dokonce ,znovuobjeveny“ - tedy $\mathrm{v}$ daný okamžik ještě neevidovány.

Součástí sbírky v olomoucké knihovně je zlomek písně Smutné a bolestné loučení Panny Marie (V Praze, tiskem Antonína Reuna, 1858). Dárcem byl dr. Miloš Kvapil z Prostějova. Špalíček 602.067 byl původním majetkem prof. Karla Sedláka z Olomouce, vykazuje stopy hojného používání, je dosti opotřebován. Je šitý, chybí mu vazba. Na konci je ručně psaná píseň.

Špalíčky 602.035 (obsahuje 52 písní, například světskou píseň Nová píseň o hrozném mordu, který se stal u města Konice v kraji holomouckém 12. února 1861 v dědině Břesko nazvaný, vytištěná v Olomouci u Antonína Halousky), 225.584 byly původním majetkem salvatoriánů v Prostějově. ${ }^{3}$

U špalíčků 602.044, 602.046, 602.050, 602.053, 602.065, které obsahují písně z přelomu 18. a 19. století, známe konkrétního majitele. Byl jím ThLic. Jiří Antonín Pustějovský ${ }^{4}$ z kláštera salvatoriánů v Prostějově, který se zde věnoval mj. osvětě stran tisku a literatury. Podobně jako u ostatních mužských řeholních domů v tehdejším Československu byla činnost salvatoriánů $\mathrm{v}$ Prostějově násilně přerušena roku 1950 tzv. Akcí K - zabráním a rušením mužských řeholních domů. Lze tedy předpokládat, že se kramářské písně, podobně jako $\mathrm{v}$ té době ostatní kulturní památky, dostaly do Vědecké knihovny v Olomouci prostřednictvím svozů zabaveného majetku.

$\mathrm{V}$ průběhu výzkumných prací bylo objeveno 50 doposud neevidovaných kramářských písní po bývalém řediteli Vědecké knihovny v Olomouci Bohuši Vybíralovi. Zůstaly zařazeny v původních složkách dle rozdělení původního majitele. Jedná se o velmi zachovalé jednotliviny, některé jsou nerozřezané a očíslované.

Zajímavostí je také nabytí nového daru způsobem čistě náhodným, který však v akviziční činnosti není výjimečným. Dva špalíčky ${ }^{5}$ byly zanechány neznámým dárcem na vrátnici knihovny. Oba jsou bez vazby, šité relativně jemnou nití, zachovalé s výraznými stopami používání, některé listy jsou potrhané. Neobsahují vpisky.

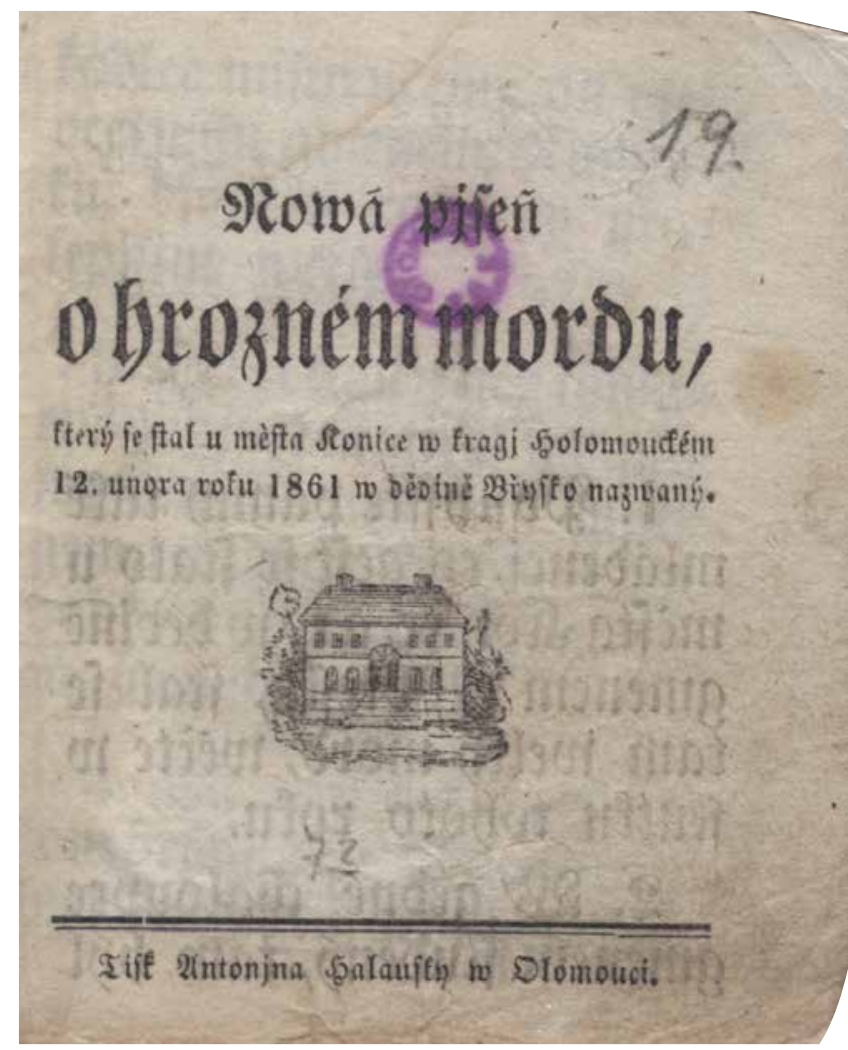

Obr. 1. Špalíček kramářských písní 602.035. Nová píseň o hrozném mordu, který se stal u města Konice v kraji holomouckém 12. února 1861 v dědině Břesko nazvaný, vytištěná v Olomouci u Antonína Halousky. (Vědecká knihovna v Olomouci).

Nejasný původ je u jednotlivin z let 1783-1877. Nejstarší tisk je evidován pod číslem 128.641 Písně ranní velmi známé, jedné každé pobožné duši zpívati velmi potřebné (V Brně u Jakuba Maxmiliána Svobody, 1730). Ve sbírce převládají písně duchovní věnované Panně Marii (Cellenské, Svatohorské, Hostinské, Svatokopecké), Ježíši Kristu, sv. Janu Nepomuckému, sv. Salvátoru či Máří Magdaléně. Mezi světskými náměty se objevuje např. Nová píseñ o přehrozném zázraku jednoho děvčete, které 200 dní nic nejedlo a při zdravém živobytí zůstalo (tiskem M. F. Lenka ve Znojmě, nedatováno) nebo Píseň o pronásledování katoliků v Turcích (tiskem Josefiny Bergerové, 1871). Písně byly tištěné ve Znojmě u M. F. Lenka, v Brně u Jakuba Maxmiliána Svobody, v Olomouci u Antonína Halousky, v Litomyšli u Josefiny Bergerové a ve Skalici u Škarnicla a synů, u Jozefa Škarnicla a u F. X. Škarnicla a syna. Jsou opatřeny razítkem evidence muzea s datem 4. 12. 1969. Jiné datum 10. 12. (?) 1964 najdeme u položek 602.067 a 602.040. K bližším záznamům evidence jsem se nedostala. Podstatným poznatkem je, že některé položky jsou opatřeny

\footnotetext{
3 Společnost Božského spasitele, hovorově označována jako salvatoriáni, je římskokatolickou řeholní společností. Založena byla ve druhé polovině 19. století, církevně schválena byla v roce 1885. Zakladatelem byl německý kněz Jan Křtitel Jordan, řeholním jménem František Maria od Kříže Jordan. Salvatoriáni v Prostějově působili v letech 1934-1950, následně se do Prostějova vrátili v roce 1990. Opravili kostel a faru, v koleji vytvořili i sídlo provincialátu. Salvatoriáni 2021, [online].

${ }^{4}$ ThLic. Jiř́i Antonín Pustějovský (29. ledna 1910 v Lichnově - 26. září 1974 v Lichnově) byl synem kostelníka Antonína Pustějovského. Ordinován byl v Rímě 18. července 1937. Jeho působištěm bylo postupně Valašské Meziř́čć, Brno-Husovice, Vranov u Brna a Prostějov. Po roce 1950 byl perzekvován komunistickým režimem, v letech 1961-1968 byl vězněn. Dne 8. července 1968 se bez státního souhlasu vrátil k službě duchovního v Lichnově. Rímskokatolická farnost Lichnov a Vlčovice 2021, [online].

5 V době mého průzkumu neměly tyto špalíčky přiřazené žádné evidenční číslo.
} 
číslem finanční částky. Dá se tedy usuzovat, že knihovna tyto položky získala nákupem v antikvariátech.

\section{Moravská zemská knihovna v Brně}

Sbírka kramářských tisků v Moravské zemské knihovně v Brně čítá asi 41000 jednotek a lze ji rozdělit na dvě nestejně rozsáhlé části. Menší část, cca 770 jednotek (z toho je 15 konvolutů sešitých z 595 písní a 175 samostatných tisků) stojících na signaturách ST1, STS a ST-PK, je součástí kmenového fondu knihovny. Všechny tyto tisky jsou zpracovány a jsou dohledatelné přes OPAC (elektronický katalog). Tisky jsou z rozmezí let $1650-1889$, z toho 10 (cca $1 \%$ ) je ze 17. století, 260 (cca $34 \%$ ) je z 18. století a 500 tisků (cca $65 \%$ ) je z 19. století. Kmenový fond MZK obsahuje z drtivé většiny kramářské písně, jen dvě jednotky jsou modlitby (STS-0510.548 a STS-0515.469 - Modlitba ke třem králům, s pripojeným čtením svatého Jana a Sedm Nebeských Zámků). Všechny tisky jsou české. Ve fondu je obsažen pouze jeden rukopisný opis kramářské písně. Špalíčky nesou stopy používání, všechny jsou více či méně poškozené. Bud' mají zachované původní, podomácku vyrobené usňové, plátěné či papírové obálky, nebo je zachováno pouze šití bez obálky. Třri jsou převázány do polousňové vazby. Samostatné písně mají v drtivé většině př́ipadů novodobou plátěnou vazbu nebo jsou uchovávány v papírových obálkách.

Provenience lze u kmenového fondu sledovat u 29 jednotek. Při prozkoumávání tohoto fondu se můžeme setkat se jmény Marie Raček v Přibyslavi (1851), Johann Dostal (1859) nebo Tomass Hora. Pravděpodobným majitelem minimálně jednoho přívazku ze špalíčku ST1-0294.173, přiv. 31 byl jistý řezník Jan M... z Chrastě (příjmení je bohužel nečitelné). V kmenovém fondu najdeme i kramářské tisky s razítky a značkami oficiálních institucí jako: Státní pedagogická knihovna Brno (jedna z knihoven, která se stala základem ke vzniku MZK), Matice Moravská anebo Moravský zemský archiv v Brně). Čtyři signatury (ST1-1216.780 - vytištěné v Př́brami roku 1616; ST1-1216.781 z roku 1842, ST1-1216.784 - vytištěno v Jihlavě u Jana Rippla, 1860; STS-1216.787 - v Litomyšli [František Berger], 1849) se v Moravské zemské knihovně ocitly jako dar v srpnu roku 2008 od brněnských lékařù Jarmily Skutilové, Jana Skutila a Martina Skutila. V signatuře ST1-1216.781 lze nalézt provenienci: [razítko] Jos.
Kalous. Mezi nejnovější přírůstky patří novodobé nákupy z let 2017 od Martina Fajtla z Kroměříže (STS-1394.092 špalíček písní z let cca 1781-1870; STS-1394.093 - špalíček z let 1801-1870). Nejčerstvějším přírůstkem je nákup z října roku 2018 z pražského Antikvariátu Ztichlá klika (ST1-1412.894 - z roku 1685: SSENEK, Emanuel. Jistá a pravdivá novina o jednom lakomém a skoupém boháči v Zemi Durynské v Městě Altsstatu, kterak jest všemohoucí Pán Bůh jeho hrozně strestati ráčil roku pominulého, a jak ten člověk lakomý z světa sešel, o čemž v písničce šiřeji obsaženo jest). Tisk pochází z pozůstalosti Rudolfa Hlavy.

V současné době je největším celkem kramářských písní v Moravské zemské knihovně sbírka jejího bývalého zaměstnance, knihovníka a knihovědce specializovaného na zpracování starých tisků a rukopisů, PhDr. Jaroslava Vobra. ${ }^{6}$

Pozůstalost Jaroslava Vobra Moravská zemská knihovna zakoupila v roce 2015 přímo od Vobrovy rodiny. Čítá cca 40000 jednotek. Z toho je 800 špalíčků (v těch je vyvázáno 26000 jednotek) a z 14000 volných (nesvázaných nebo naopak rozvázaných) kramářských tisků. ${ }^{7}$ Jaroslav Vobr vypracoval ke své sbírce rozsáhlý lístkový katalog, názvově abecedně řazený, obohacený o věcný popis ve formě klíčových slov. Lístky obsahují tiskařské údaje bud'to převzaté z impressa, nebo určené dodatečně. Každý špalíček je navíc opatřen lístkem obsahujícím signaturu, počet kramářských písní nebo modliteb ve špalíčku, rozpětí let vydání, místa vydání (oboje bud'to čerpané prímo z knihy, anebo dohledané J. Vobrem) a popis, zda jde o český nebo německý tisk. Dále je většina tisků opatřena lístečky s referencemi na odbornou literaturu, knihopis (i negativní citace) nebo jiné soupisy, popř. instituce, které totožné vydání kramářského tisku vlastní. V nekompletních tiscích bez titulních listů jsou vloženy lístečky s dr. Vobrem dohledaným názvem písně.

Další informace se týkají pouze konvolutů, nebot' volné tisky uložené $\mathrm{v}$ krabicích a setříděné vesměs podle tiskařů jsou zatím zpracovány jen z malé části. Obsah konvolutů v drtivé většině tvoří kramářské písně (přes 24700 jednotek). V řádech jednotek kusů se objevují také kalendáře nebo minuce (např. VK-000.385,12, Minuce), evangelia (VK-0000.385,14a), kázání (VK-0000.616,9, Kázání k vysvěceni poutního kostela Nanebevzetí Panny Marie na Hostýné), nekrology (VK-0000.726,38, Nekrolog Karla Filipa Schwarzenberga). 6\% (1 560 jednotek) jsou modlitby z let 1726-1900. Těch je 1500 jazykově českých (z let

\footnotetext{
${ }^{6}$ PhDr. Jaroslav Vobr (25. května 1939 Praha - 29. května 2013 Brno) byl pražským rodákem, který ale vyrostl a studoval v Jihlavě. Jeho původní profesní směřování však nevedlo mezi knihovní regály. Po složení maturity v roce 1956 v Jihlavě získal ve stejném městě umístěnku do Městského stavebního podniku. O tři roky později začal studovat stavební průmyslovku v Brně. Po ukončení povinné vojenské služby získal místo v Podniku bytového hospodářství Brno III. Jeho velký zájem a pozoruhodné znalosti z knihovědy ho svedly dohromady s jeho pozdějším kolegou Vladislavem Dokoupilem. Svým výjimečným nadáním, speciální znalostí v oboru prvotisků a starých tisků přesvědčil Vobr i tehdejšího ředitele Státní vědecké knihovny (dnešní Moravské zemské knihovny v Brně) Miloše Papírníka a 1. června 1965 se stal zaměstnancem knihovny. A to již jako student dálkového studia knihovnictví na Univerzitě Karlově. V roce 1971 složil rigorózní zkoušky a získal titul doktora filozofie. V knihovně brzy působil souběžně na úseku bibliografie společenských věd a starých tisků. Společně s V. Dokoupilem vydali řadu soupisů, např. tisky 16. století ve fondech Státní vědecké knihovny (dnešní Moravské zemské knihovny) nebo dílo Jana Amose Komenského ve fondech SVK. Vedle řady zpracovaných soupisů a bibliografií se objevují mj. i publikované studie: Kramářská písen̆ o pádu stonařovského meteoritu roku 1808 (Vlastivědný sborník Vysočiny, VS, 3, 1969), Dalši kramárské písně o stonařovském meteoritu (tamtéž, 6, 1988), které dokazují jeho odborný zájem o kramářské písně. V roce 2001 jej postihla mozková př́hoda, na jejímž základě o rok později požádal o odchod do důchodu.

7 Špalíčky jsou katalogizačně zpracovány všechny, 200 s knihou v ruce, zbylých 600 přepisem z lístkové evidence, kterou Jaroslav Vobr ke své soukromé sbírce vypracoval. V současné době probíhá zpracování 15000 volných tisků. Konvoluty jsou tedy dohledatelné přes OPAC (elektronický katalog) všechny, samostatné písně zatím jen zčásti. Tato akvizice stojí na signatuře VK a veškeré práce na ní probíhají v rámci projektu NAKI (Program na podporu aplikovaného výzkumu a vývoje národní a kulturní identity) Kramářské písně v brněnských historických fondech.
} 
1726-1900, cca 60 z 18. století, zbytek, tzn. 1440 , ze století 19.) a 60 německých z let $1730-1880$ ( 50 z 19. století a 10 je z 18. století). Kramářské písně jsou z let 1650-1920, 220 jich je německých ( 56 z 18. století, 164 z 19. století, některé jsou vyvázány do špalíčků, kde jinak převažuje čeština (např. VK-0000.277 obsahuje písně i modlitby v češtině a němčině, jiné jsou jazykově zcela německé (např. signatury VK-0000.446, VK-0000.447 obsahují 67 německých písní), 50 jednotek z let 1653-1910 je dvojjazyčných - německých a českých (např. souběžný český a německý text se objevuje v signatuře VK-0000.003,11), 8 písní z let 1831-1860 je polských. Několik písní obsahuje slovenštinu (např. VK-0000.570,22 Pieseň ku cti a chvále blahosl. Panny Marie, patronky sv. Ruženca). Latina se objevuje jen zrrídka (např. Te Deum Laudamus, název písně v latině, zbytek v češtině).

24500 jednotek je českých, nejstarších asi 60 písní je z druhé poloviny 17 . století, cca 4000 písní je z 18 . století, většina, tj. asi 20000 písní, je z 19. století a 100 písní je z 20. století. Není žádnou vzácností, že si majitelé špalíčků některé písně, modlitby opisovali i vlastnoručně (někdy se ve špalíčcích objevují i rukopisy více osob). Ve špalíčcích se signaturou VK je vyvázáno cca 120 rukopisů z let 1796-1925. Z toho dva jsou ze 20. století, cca 100 ze století 19., 11 odhadnutých na přelom 18. a 19. století a jeden z roku 1796. Jak je u kramářských tisků obvyklé, až na pár tisků (z nejvýznamnějších jmenujme na 400 písní připsaných flašinetáři, prodejci a autoru kramářských písní Františku Haisovi, 1818-1899, a 50 písmáku a autoru kramářských písní Josefu Térovi, 1811-1897) zde není určitelné autorství.

Pokud budeme procházet Vobrovu sbírku kramářských písní, která čítá 40000 jednotek kramářských tisků, pak můžeme speciálně na některých špalíčcích zachytit ex libris Jaroslava Vobra s jednotlivými datacemi z let 19642000 (1964, 1965, 27. 1. 1967, 1969, 27. 12. 1971, 1972, 28. 3. 1972, 3. 7. 1972, 4. 10. 1972, 30. 11. 1973, 27. 2. 1974, srpen 1974, 16. 4. 1975, 28. 4. 1976, 21. 9. 1977, 27. 4. 1978, 14. 10. 1991, 14. 9. 2000). U jednoho z posledních záznamů je Jaroslavem Vobrem připsáno: „Koupil jsem 14. 9. $2000 \mathrm{v}$ této špalíčkové pseudoúpravě.“ ([Česko?]: [mezi 1789 a 1831?]; VK-0000.752). Tyto informace bývají zaznamenány bud' na předních či zadních př́deštích jednotlivých špalíčků, príípadně na kartonových pouzdrech, která k lepšímu archivování př́mo pro jednotlivé kusy nechal Vobr vyrobit.

Vedle Vobrových ex libris jsou ve špalíčcích také razítka. Např́iklad razítko Václava Kozáka (kramářské písně označené tímto razítkem se pohybují v rozmezí od konce 18. století - 1873). Razítko B. V. [Broukal Václav] ${ }^{8}$ se objevuje ve špalíčcích obsahujících písně cca z let 1701-1920. Výskyt této značky je četný, nalezen prozatím řádově v cca 80 př́padech. Podobně četný výskyt, i když o něco nižší, má razítko s iniciálou J. G. Tato značka se povětšinou vyskytuje ve shodných špalíčcích jako značka B. V. Na rozdíl od předešlého př́ípadu se však $\mathrm{k}$ těmto iniciálám nepodařilo prozatím přiřadit konkrétní jméno pravděpodobného původního majitele. Ve Vobrově sbírce lze nalézt také razítko Al. Adamus, Turnov (písně z let 1793-1900), razítko A. Borovský (asi 1848), Joh. Läska (1848-1849), četnější výskyt lze zaznamenat u razítka Ze sbírky R. Hlavy ${ }^{9}$ (1685-1900). Další jména, která se ve sbírce objevují, jsou např. Václav Kut'ák ${ }^{10}$ (1789), Jan Weger (písně z let 17511820), Jaroslav Červený ${ }^{11}$ - Kutná Hora (1831), nebo Frant. Branšovský v Kojetíně.

Narazíme také na zřejmě cenzorské poznámky, např. pr. 23/7.1879. 101 (VK-0000.258).

Zajímavé jsou i rukopisné poznámky, které se při procházení kramářskými písněmi badateli objeví před očima. Často v písních nacházíme i podpisy (mnohdy bohužel nečitelné). Texty jsou občas doplněné i malůvkami.

Zde jen pár př́íkladů:

- [Na listu 3b pozdější príípis] Tuto píseň psal jistý p. Šebek, též Kubeš zvaný, učitel ve Vesci (pod Řipem) ([Česko?], 1828; VK-0000.521,10),

- [m. p.] Milé Alence na památku dává babička Boh. Novotná 21. 5. 1934 (Vytištěná v Chrudimi: 1831; VK-0000.709),

- od P. Cyrila Tichého ${ }^{12}$ ze sbírek Bartošových v reálce v Brně (Česko?: [mezi 1864 a 1880?]; VK-0000.603); (Česko?: [mezi 1810 a 1865?]; VK-0000.609); (Česko?: [mezi 1780 a 1841?] a ([Litomyšl?]: [mezi 1801 a 1870?]; VK-0000.621); VK-0000.610),

- Ex Libris Fr. Křemen ${ }^{13}$ E 79; pohled na Vltavu a Písek, nahoře znak Písku (foto) (VK-0000.185),

\footnotetext{
${ }^{8}$ Pravděpodobně Václav Broukal (7. 9. 1894 Žarošice u Kyjova - 7. 12. 1972 Žarošice u Kyjova); byl vlastivědný a kulturní pracovník, archeolog, autor časopiseckých článků a prací z oboru archeologie.

${ }^{9}$ Rudolf Hlava (13. 4. 1911 Př́krý, okr. Semily - 5. 11. 1988) byl učitelem, muzejním archivářem a městským kronikářem v Semilech (1946-1988). Zasloužil se o vznik památníku Antala Staška a Ivana Olbrachta. Byl sběratelem kramářských a dělnických písní, kupletů, sbíral také drobnou grafiku a ex libris. Svoji největší soukromou sbírku kramářských písní v tehdejším Československu odkázal Národnímu muzeu v Praze.

${ }^{10}$ Pravděpodobně narozen 8. 11. 1876 v Jaroměři, zemřel asi 21. 1. 1956 v Ústí nad Orlicí. Byl učitelem, pracovníkem státní ochrany prírody, publikoval časopisecké články z oboru.

${ }^{11}$ Pravděpodobně narozen 14. 3. 1881 v Kutné Hoře, zemřel 30. 3. 1956 tamtéž. Byl odborným publicistou, napsal spisy o dějinách knihtisku, historické monografie, črty a povídky.

${ }^{12}$ Pravděpodobně narozen 22. 6. 1912 v Krasonicích, katolický kněz, doktor teologie.

${ }^{13}$ Pravděpodobně František Křemen (16. 1. 1870 Praha - 1. 8. 1934 Praha). Odmaturoval 1888 na gymnáziu v Litomyšli (kde k jeho učitelům patřil i Alois Jirásek), pokračoval ve studiu na filozofické fakultě pražské univerzity. V letech 1896-1919 vyučoval češtinu a němčinu na písecké reálce, kde jedním z jeho kolegů byl i básník Adolf Heyduk. Brzy po svém příchodu do Písku pomáhal Heydukovi s jazykovou úpravou jeho souborně vydávaného básnického díla. Tato činnost byla také podnětem ke Křemenově studii Adolf Heyduk. Pokus o rozbor jeho díla, která vyšla poprvé ve výročních zprávách písecké reálky na léta 1906-1908. Z píseckého archivu, při jehož usporádání pomáhal Augustu Sedláčkovi, čerpal Př́spěvky do českého slovniku, které publikoval v Listech filologických (1917-1918). V knihovně píseckého muzea objevil barokní báseň z roku 1712 Epibateron, která vyšla také v Listech filologických. Bádání v archivech znamenalo pro F. Křemena celoživotní zálibu a inspirovalo ho k napsání četných „kulturních obrázků“. V roce 1919 se přestěhoval do Prahy, kde působil na malostranské reálce až do roku 1929. Křemenova dcera Zdeňka Křemenová, malířka a ilustrátorka, uveřejnila v novinách a časopisech více než 100 literárních prací svého otce, které doprovázely její vlastní ilustrace. ČTENÍ Z PÍSKU 2021, [online].
} 
- na rubu titulního listu Lojzinka Hladišova v Přerově narozena 18 Ledna Roku 1888 (VK-0000.167),

- od p. Karla Hlineckého z Čejkovic ([Česko?]: [mezi 1845 a 1867]; VK-0000.614),

- [m. p] Od pí Anežky Těšné z Bítova 28. 3. 1970 (v Jihlavě: [mezi 1832 a 1870?]; VK-0000.617),

- p. Al. Hebelky z Lidokovu (z půdy) ([Česko?]: [1833?]; VK-0000.620),

- František Josef Ručka (v Litomyšli: [mezi 1863 a 1874?]; VK-0000.644, př́iv. 20),

- Řiháček Emil Dolní Kounice (v Budíně: [mezi 1847 a 1863?]; VK-0000.665),

- [m. p.] Paulík K Kapelník (V Skalici: 1844; VK-0000.673),

- [m. p.] Skleničková Zdeňka ([Česko?]: [mezi 1851 a 1870?]; VK-0000.681, př́iv. 20),

- [m. p.] Sebral Václav Sadeckej 1897 (K dostání v Praze: [1848?]; VK-0000.682),

- $\quad$ [m. p.] sehnal Václav Lavecký 1897 (V Praze: 1848; VK-0000.682, př́v. 25),

- Tato práce jest s boží pomocí a milosti ducha swatého ode mně Františka Zlatohlávka z Poříče ... pro Annu Těschitel, dcerušku pana Joh. Těšitel souseda pardubického ... léta Páně 1819 , v roku mého věku v 70 ([Poříčí u Litomyšle]: 1819; VK-0000.068),

- Koupeno od pí Růženy Vaňáčkové, Klajdovská 43, Brno-Líšeň, narozené roku 1901. Písně měla po své prababičce Anně Popelákové, roz. Hodajnové. V Brně 22. února 1979 (foto) (?): 1798-1800-1856; VK-0000.003,78),

- Tento špalíček byl stařenky Františky Libigerové z Dolního Újezda č. 2 (rozené Dohnalové 17.XI1840-Jezernice)[?](Praha;VK-0000.240,116).

\section{Muzeum jihovýchodní Moravy ve Zlíně}

Sbírka kramářských písní v Muzeu jihovýchodní Moravy ve Zlíně ${ }^{14}$ je zařazena $v$ Etnografickém fondu. Není př́liš obsáhlá, čítá 175 položek, kromě jednotlivin obsahuje také několik špalíčků, a to v různém stupni zachovalosti. Většina kramářských písní pochází ze sbírkového fondu bývalého Krajinského muzea ve Vizovicích. Bohužel údajů o jejich původu se zachovalo minimum. Menší část je ze sběrů soukromého majitele a několik nejnovějších přírůstků je z darů nebo náhodných nálezů.
Tato sbírka obsahuje nevelké množství jednotlivin. Počtově se téměř vyváženě věnují světským a duchovním tématům. Většina $\mathrm{z}$ nich byla vydána $\mathrm{v}$ Litomyšli a pochází $\mathrm{z}$ dílen V. Augusty, Františka Bergera a především Josefiny Bergerové. Dva kusy byly vydány ve Skalici u dědiců J. Škarnicla.

Lze tu najít i kramářské písně ze sbírky Jaroslava ŽílyLipjana, ${ }^{15}$ který ji muzeu věnoval roku 1943. Příkladem je světská kramářská píseň E-4973 - Kořalka pekelná (bez vydavatele, nedatováno), na níž můžeme najít razítko s textem: Sbírka Jaroslava Žíly věnováno vizovickému muzeu. Jaroslav Žíla-Lipjan byl nadšeným badatelem a vlastivědným pracovníkem, který se věnoval i osvětové a spolkové činnosti. V letech 1951-1964 působil jako ředitel Okresního muzea v Novém Jičíně. Patřil také mezi zakladatele Památníku Františka Palackého v Hodslavicích. ${ }^{16}$ Úzce spolupracoval s Muzejním spolkem ve Vizovicích a vizovickým Krajinským muzeem. ${ }^{17}$

Neopomenutelnou část sbírky kramářských písní sestavil etnograf, folklorista a muzejník PhDr. Karel Pavlištík, CSc., ${ }^{18}$ který nastoupil v dubnu 1962 do tehdy Oblastního muzea jihovýchodní Moravy. Jako vedoucí oddělení společenských věd s respektem navázal na práci svých předchůdců i na jejich odborný odkaz. ${ }^{19}$ Hned po svém nástupu byl pověřen vytvořením nové národopisné expozice na zámku ve Vizovicích, jejímž účelem bylo představit doplňková zaměstnání obyvatel Podřevnicka, hlavně zpracování dřeva. Za tímto účelem se Pavlištík rozhodl podniknout rozsáhlý terénní výzkum, jehož součástí byl i sběr sbírkového materiálu. Navázal intenzivní spolupráci se školami v celém regionu, kdy se žáci a studenti podíleli na vyhledávání především dřevěného nářadí domácí výroby. A právě z této aktivity vzešly i nové muzejní přírůstky kramářských písní. ${ }^{20}$

Ke sběru Karla Pavlištíka patří duchovní kramářské písně E-4249 - E-4258, které muzeu věnovala Jindra Bočánová z Uherského Brodu. Byly jejím dědictvím po matce Karolině Šuranské. Většina $\mathrm{z}$ nich jsou jednotliviny rozměru malé šestnácterky, E-4258 je formátu $11 \times 17,5 \mathrm{~cm}$. Pocházejí z Litomyšle, Hranic či ze Skalice (Škarniclové), datace většinou chybí, uvedena jsou tři data - 1854, 1855, 1856. Položka E-4254 je špalíčkem duchovních kramářských písní sešitých režnou nití, velikosti $17,5 \times 10,5 \mathrm{~cm}$. Písně pocházejí z let 1842-1856 (některé jsou nedatovány), většina byla vytištěna ve Skalici u Škarniclů, po jednom

\footnotetext{
${ }^{14}$ Na počátku existence dnešní podoby muzea byl vznik dvou samostatných muzeí. V roce 1930 bylo otevřeno Bat’ovo museum ve Zlíně. V roce 1944 bylo schváleno zřízení Městského musea ve Zlíně. Spojením městského muzea a muzea obuvnického bylo 1. 1. 1953 oficiálně ustanoveno Krajské museum v Gottwaldově. V roce 1958 byla do muzea začleněna i Krajská galerie a název se změnil na Krajský vlastivědný ústav. V červenci 1961 se galerie znovu osamostatnila a muzeum bylo v témže roce přejmenováno na Oblastní muzeum jihovýchodní Moravy v Gottwaldově. V roce 1990 bylo muzeum přejmenováno na dnešní název - Oblastní muzeum jihovýchodní Moravy Zlín. Muzeum také zastř̌šovalo množství odloučených pracovišt - Muzeum luhačovického Zálesí, Národní kulturní památník na Ploštině, fojtství v Jasenné, vizovický zámek, větrný mlýn ve Štípě. PLÁNKA 2003, s. 11-34.

${ }^{15}$ Přestože Jaroslav Žíla-Lipjan toužil studovat na univerzitě, majetkové poměry rodiny, z níž pocházel, to nedovolily. Po celý život se živil jako bankéř v Praze, v Brně i v Moravské Ostravě, kde se stal místoředitelem banky Slavie. PRUDKÁ 2017, s. 246-249.

${ }^{16}$ PRUDKÁ 2017, s. 246-249.

${ }^{17}$ V roce 1939 začal vlastním nákladem vydávat časopis Podřevnicko, vlastivědná kronika Krajinského musejního spolku ve Vizovicích. PRUDKÁ 2017, s. 246-249.

${ }^{18} \mathrm{PhDr}$. Karel Pavlištík, CSc., externě vystudoval etnografii na Filozofické fakultě Univerzity Karlovy (1956-1960). V letech 1954-1962 působil jako tanečník, sólista a choreograf Armádního uměleckého souboru Víta Nejedlého. PRUDKÁ 2018, s. 206-210.

19 PLÁNKA 2003, s. 114

${ }^{20}$ PRUDKÁ 2018, s. 206-210.
} 


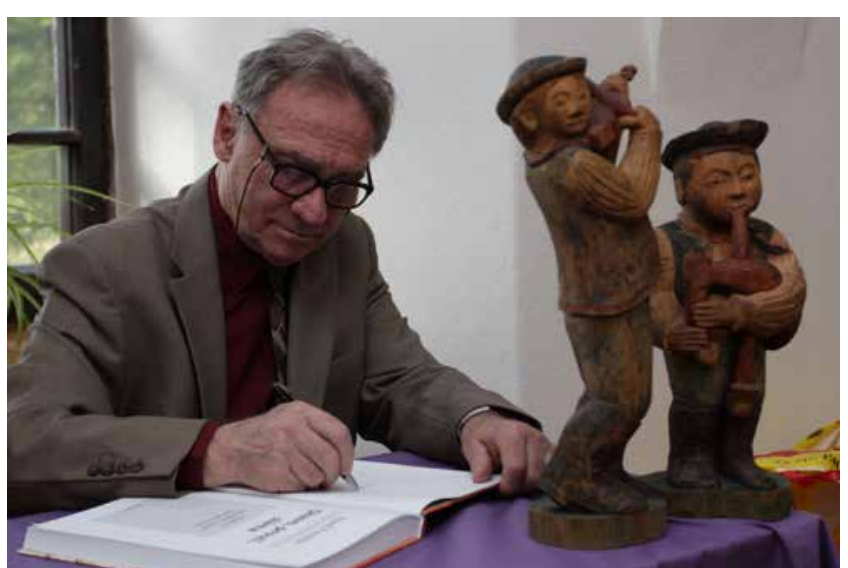

Obr. 2. PhDr. Karel Pavlištík, CSc. (Fotografie V. Křiž, uložena v archivu Muzea jihovýchodní Moravy ve Zlíně).

v Hradišti a v Hranicích.

Jedním ze zásadních dárců kramářských písní se stal přítel Karla Pavlištíka, výtvarník, malír a grafik Ladislav Včelař, který mnohokrát výtvarně zpracoval výstavy a expozice připravené dle scénářů Pavlištíka. ${ }^{21}$ Kromě svých vlastních děl věnoval muzeu i řadu kramářských písní, které sbíral v 50. letech 20. století. Jedná se o jednotliviny, většinou v zachovalém stavu (občas chybí titulní list). Jsou uložené pod inventárními čísly E-4090 - E-4119. Na některých z nich je možné nalézt Včelařũv podpis, všechny jsou dnes opatřeny razítkem Oblastní muzeum Gottwaldov.

Špalíček E-20054 je darem Farního úřadu Mysločovice z roku 2010. Nález pochází z fary z období, kdy došlo k výměně faráře. Obsahuje 27 písní z let 1853-1875 svázaných do přebalu z tmavohnědé plsti. Některé špalíčky muzeum zakoupilo: od Marie Budíkové z Frenštátu pod Radhoštěm z pozůstalosti její babičky Veroniky Břešt’ákové koupilo muzeum dvě duchovní písně (E-12538) tištěné ve Skalici v letech 1863-1871; špalíček E-17349 písní z let 1798-1877 tištěných v Praze, v Olomouci, ve Skalici (Škarniclové) či v Litomyšli (František Berger) byl zakoupen od Jany Koulové ze Zlína - z rodinného dědictví; Marcela Krumpolcová prodala muzeu špalíček písní z let 1850-1871 (E-17368); Josef Kučera daroval špalíček písní z let 1850-1870 (E-18834).

Zatím posledním prrírůstkem do sbírek muzea je unikátní špalíček kramářských písní získaný darem z rodinného dědictví dárce. Jednotliviny jsou sešité režnou nití a opatřeny obalem z režného plátna. Obsahuje písně z let 1815-1866, většina $\mathrm{z}$ nich přináší duchovní tematiku, součástí jsou však i písně světské, např. Piseň o robotě z roku 1848 nebo témata mravoučná či zpravodajská s tématy zločinů. Milostná tematika v tomto špalíčku chybí. ${ }^{22}$

\section{Slovácké muzeum v Uherském Hradišti}

Sbírka kramářských písní je ve Slováckém muzeu v Uherském Hradišti ${ }^{23}$ uložena ve dvou odděleních. ${ }^{24}$ Větší část spravuje oddělení historie, kde je uloženo 256 jednotlivin (inv. čísla H 2465 - H 2670, H 2684 - H 2699, H 2800 H 2834, H 3651, H 3652, H 9265) a také tři špalíčky (inv. čísla H 2835, H 2836, H 2837). V etnografickém oddělení je umístěno 16 jednotlivin (inv. čísla E 35.166 a E 35.042 E 35.056) a jeden špalíček (inv. číslo E 35.201), které jsou z pozůstalosti Bohuslava Beneše. ${ }^{25}$ Písně jsou povětšinou velmi zachovalé, poškozených je relativně málo.

„Téměř celý soubor kramářských písní z oddělení historie (až na tři písně) byl získán převodem od etnografického oddělení. Převod probíhal od listopadu 1980 do 21. dubna 1981. Na etnografickém oddělení soubor nebyl zpracován a nebyla pro něj zavedena ani žádná evidence, proto dnes nelze zjistit původ písní před jejich nabytím. " ${ }^{26}$ Následně o sbírku pečovala Mgr. L. Tarcalová.

Převážná část kramářských písní má duchovní tematiku z období 20. let 18. století po počátek 19. století. Mezi nejstarší položky patří Písně o blahoslavené Panně Marii (tištěná kolem roku 1730) a Pisně dvě v nově vydané $k d u$ chovnímu potěšení v tyto zarmoucené časy spivati užitečné (Brno, 1733). Většina se obrací k Panně Marii (Cellenské, Svatokopecké, Svatokřtinské, Hostýnské, Žarošické, Svatohorské, Šaštínské, Tálské, Topol’čanské, Tuřanské, Velehradské, Staroboleslavské, Častochovské, Bzenecké), mnoho k sv. Janu Nepomuckému. Ve větší míře byly písně tištěny v Olomouci (Jan Adam Avinger, František Ant. Hirnle, Antonín Halousek, Josef Groák), v Litomyšli (Václav Vojtěch Tureček, František Berger, Antonín Augusta, Josefina Bergerová), v Brně (Emanuel Svoboda, Jan S. Siedler, Rudolf Rohrer), v Uherském Hradišti (Antonín E. Zanner, Bratřri Handlové), v Jihlavě (Jan Rippl), ve Skalici (Josef Škarnicl, F. X. Škarnicla synové, Teslík a Neumann) nebo ve Znojmě (Martin Hofmann).

Nákupem z pozůstalosti Bohuslava Beneše získalo muzeum špalíček E 35.033 v papírové vazbě s plátěným hřbetem, šitý hrubou nití (volné dírky napovídají, že byl přešívaný). Vykazuje stopy častého používání, je bez vpisků. Nákupem v roce 1990 se do muzea dostaly dvě písně - inv.

\footnotetext{
${ }^{21}$ PLÁNKA 2003, s. 115.

22 iDNES.cz 2021, [online].

${ }^{23}$ Pro potřeby vzniku muzea (k jehož existenci dala podnět Národopisná výstava českoslovanská v Praze, 1895) uvolnila městská rada prostory v bývalé jezuitské koleji. Právě zde byly sbírky instalovány. Samotné muzeum bylo slavnostně otevřeno 1. června 1914. Rok 1918 znamenal pro muzeum uzavření - na jeho místě vznikla kasárna. V březnu 1919 byla nově ustavena Národopisná a muzejní společnost, ale nové prostory pro muzeum byly otevřeny až 15. srpna 1931. Druhá světová válka aktivity muzea přerušila, znovu otevřeno bylo až v roce 1946. Přibyly pobočky Památník Velké Moravy ve Starém Městě, Galerie výtvarných umění v Uherském Hradišti, dočasně lapidárium na Velehradě a městské muzeum v Bojkovicích. FROLEC 2000, s. 9-10.

${ }^{24}$ Pozoruhodnou sbírku kramářských písní ve Slováckém muzeu v Uherském Hradišti velice podrobně popsal Norman Černý ve své bakalářské práci.

${ }^{25}$ Bohuslav Beneš se zajímal o pohádky a pověsti a zároveň je sbíral. Sbíral i další artefakty, nakupoval v antikvariátech. Po smrti vše odkázal Slováckému muzeu v Uherském Hradišti. Tato vazba vycházela i z přátelství s kurátorkou Slováckého muzea Mgr. Ludmilou Tarcalovou. V roce 2011 zakoupilo muzeum další předměty ze soukromé sbírky Bohuslava Beneše od jeho syna Radúze Beneše.

${ }^{26}$ ČERNÝ 2010, s. 20-21.
} 
čísla H 6351 a H 6352. Další dva špalíčky získalo muzeum darem od Emilie Novákové z Bánova (E 35.201) a roku 2007 koupí od M. Náplavové z Osvětiman ${ }^{27}$ (pod přírůstkovým číslem 53/2007), které získaly tyto artefakty jako dědictví po rodičích.

\section{Muzeum Komenského v Přerově}

Paradoxně jednu z nejpočetnějších sbírek kramářských písní z námi sledovaného souboru - obsahující cca 3000 jednotek, $\mathrm{z}$ nichž se téměř dvě třetiny věnují duchovní tematice - lze stran postupného vytváření velmi těžce mapovat. A to i přesto, že téměř celá sbírka je precizně zpracována její bývalou kurátorkou M. Pískovou. Badatelé mají možnost listovat pečlivě vytvořenými evidenčními kartami, které kromě podrobného popisu jednotlivých exemplářů (zařazení $\mathrm{v}$ rámci muzea, inv. a přír. číslo, název, nápěv, datum a místo vydání, tiskař, způsob nabytí, formát, stav, slovní popis titulního listu) obsahují i sken titulního listu a které jsou svázány do několika úhledných knih v červené vazbě.

Z historie původu a zařazení kramářských písní bylo z dostupných materiálů zjištěno následující: Jádro podsbírky Muzea Komenského v Přrově ${ }^{28}$ pochází ze sbírek Městského muzea v Přerově. V roce 1988 patřily kramářské písně do fondu tiskovin a sbírka čítala 93 jednotek. V roce 1992 bylo do prírůstkové knihy zapsáno 1537 jednotek kramářských písní převedených ze Školského úřadu. Kramářské písně jako celek byly do roku 1993 součástí sbírky starých tisků. Následně byly vyňaty a zpracovány systematickou evidencí jako samostatná sbírka. Do fondu bylo začleněno také více než 1000 jednotek původně z městského muzea v Hranicích, které bylo v 70. a 80. letech 20. století součástí celku Okresní vlastivědné muzeum Přerov. Jednalo se o exempláře z knihovny lékaře, národního buditele a spisovatele J. H. A. Gallaše (do sbírkové evidence přerovského muzea byly zapsány v roce 1979). Dalších 152 jednotek bylo zapsáno v roce 1994 jako staré sběry muzea, tedy z neevidovaných fondů.

Naposledy se sbírka rozrostla o 24 jednotlivin (inv. čísla J2785-J2808) z let 1731-1868 zakoupených od Jarmily Křupkové z Olomouce v lednu 2007. Naprostá většina z nich, 22 jednotek, se věnuje světským motivům, pouze dvě se věnují tématům duchovním - obrací se k Panně Marii (Svatodubské, Svatokopecké). Vytištěny byly v Olomouci (Josef Groák), v Prešpurku, v Litomyšli (Josefina Bergerová, Antonín Halouska), v Brně, v Hranicích (Amalie Škarniclová), v Trenčíně a Těšíně.
V srpnu 2007 koupilo muzeum tři špalíčky kramářských písní od Zdeňka Patky ze Zábřehu. Špalíček 81 sešitých listů, obsahující písně duchovní i světské tištěné česky, značně poškozený (inv. číslo J2809), špalíček 112 sešitých listů, obsahující písně duchovní i světské tištěné česky (inv. číslo J2810), špalíček 111 sešitých listů, obsahující písně duchovní i světské tištěné česky, v deskách z černé textilie, značně poškozený (inv. číslo J2811).

\section{Jihomoravské muzeum ve Znojmě}

Sbírka kramářských písní a modliteb Jihomoravského muzea ve Znojmě ${ }^{29}$ je velmi ucelená a velice pečlivě zpracovaná. Bohužel specifikum tohoto muzea je, že se po druhé světové válce ztratila veškerá muzejní dokumentace. Pátrání po „cestách kramářských písní do tohoto muzea“ je tedy velmi ztížené. Vzhledem k velkému množství téměř nepoužitých, často nerozřezaných jednotlivin (převážně tištěných ve Znojmě) si dovoluji spolu s muzejníky znojemského muzea vyslovit hypotézu, že tisky byly součástí pozůstalostí rušených znojemských tiskáren, které se dostaly do muzea. Napovídá tomu i skutečnost, že v místním muzeu jsou uloženy i tiskařské štočky kramářských písní právě ze znojemských tiskáren.

Sbírka čítá 642 položek z let 1620 (?) - 1873 (většina z nich je bohužel nedatována) a kromě jiného obsahuje převážnou část tvorby znojemských tiskařu. Téměř 500 položek vydal místní vydavatel M. F. Lenk, který vydával písně i modlitby české i německé. Ostatní tisky vydali Martin Hofmann (Znojmo), Siedler'schen Schriften (Znojmo), A\&R Nawratil (Znojmo), Lenk's Druck, Verlag von Philipp Kramer (Brno), Andreas Leopold Siedler (?), Wilém Burkart (Brno), Pacák (Chrudim), Alois Landfras (Jindřichův Hradec), Jan Spurný (Praha), Jan Rippl (Jihlava), Josef Groák (Olomouc), Jan Kárl Hrába (Praha), Friedrich Hagenauer (Vídeň), Škarnicla a synové (Skalice), A. Škarniclová (Hranice), A. Augusta (Litomyšl), St. Pospíšil (Chrudim), Hynek Rottberger (Prostějov), W. Burkart (Brno), W. Hofmann (Praha), Bedřich Stýblo (Praha), K. Wetterlowská (Praha), Ignáz Eder (Vídeň), A. Pavlíček (Opava), Karel Procháska (Těšín), Antonín Halouska (Olomouc), Teslík a Neumann (Uh. Skalice), Jan Rokos (Praha), J. Kinzl (Krems), Benedictiner-Buchdruckerei (Brno) a další. V celé sbírce výrazně převažuje němčina, cca 500 jednotek. U českých tisků dvojnásobně převládají písně s motivy duchovními. Obrací se k sv. Marii (Cellenské, Sukdolské), sv. Františku, sv. Anně, sv. Janu Nepomuckému či sv. Salvátoru.

\footnotetext{
${ }^{27}$ Rozená Širůčková. Byla zaměstnankyní Slováckého muzea v Uherském Hradišti.

${ }^{28}$ Muzeum Komenského v Přerově je svého druhu nejstarším na světě. Základy muzea věnujícího se odkazu J. A. Komenského položil roku 1888 František Slaměník. Následně (v souvislosti s př́pravou Národopisné výstavy v Praze) vzniklo roku 1902 Městské muzeum. Součástí Městského muzea se postupně stávala další muzea - Teličkovo archeologické muzeum, Hudečkova sbírka hmyzu a Legionářské muzeum. Po rekonstrukci přerovského zámku se muzea stěhovala tam, včetně zatím samostatného Muzea Komenského (bylo majetkem Ústředního spolku Jednot učitelských na Moravě a Slezsku). Obě muzea - Městské muzeum a Muzeum Komenského - byla sloučena roku 1950. Roku 1956 získalo muzeum název Okresní vlastivědné muzeum J. A. Komenského. Název byl měněn ještě několikrát, od roku 1993 existuje Muzeum Komenského v Přerově. HÝBL 2001.

${ }^{29}$ Dne 12 . ledna 1878 padl návrh na schůzi řádné valné hromady německého městského spolku na zř́zení městského muzea ve Znojmě. V květnu téhož roku byly schváleny stanovy a následně kuratorium vyzvalo občany k darům či zápůjčkám hodnotných předmětů. Roku 1883 získalo muzeum dvě místnosti v prvním patře tzv. Goltzova domu, 1888 se muzeum stěhovalo do školy Františka Josefa, sbírky zpř́stupnilo v květnu 1889. Roku 1910 byly sbírky umístěny do prostor znojemského hradu, celý hrad včetně rotundy získalo muzeum do své správy roku 1920. Roku 1931 získalo název Jihomoravské krajinské muzeum. ATWERI 2008, s. 5-25.
} 
Mimo tuto sbírku se nachází jeden špalíček V609 ve sbírce Josefa Květoně, ${ }^{30}$ středoškolského profesora a učitele hluchoněmých.

Střípky informací, jak se kramářské písně do Jihomoravského muzea ve Znojmě dostávaly, lze nalézt ve Státním okresním archivu Znojmo. Např́klad 11. srpna 1953 píše vedoucí muzea děkovný list Městskému museu v Táboře za „dar jedné kramářské písničky“. Z dopisu z 28. července 1953 se dozvídáme, že se jedná o Novou písen̆ ze začátku 19. století. $^{31}$

\section{Muzeum a galerie v Prostějově}

Sbírka kramářských písní v Muzeu a galerii v Prostějově ${ }^{32}$ putovala $v$ průběhu existence muzea mezi historickým fondem a knihovnou. Stran evidence prozatím existuje pouze papírový seznam, elektronicky zatím jednotlivé položky evidovány nejsou. Fyzicky jsou kramářské písně uloženy ve třech kartonových krabicích, jedná se cca o 400 jednotek. Jednotlivé dárce kramářských písní, at' už jednotlivin, či špalíčků, lze dohledat v př́růstkových knihách muzea. V následujícím soupisu uvádím většinu $\mathrm{z}$ nich.

V roce 1926 darovala muzeu špalíček B. Tomášková, o rok později daroval další špalíček František Orel, roku 1928 získalo muzeum špalíček z první poloviny 19. století od I. Bartáka, studenta třetího ročníku obchodní akademie. Roku 1929 získalo muzeum dva špalíčky od A. Černouška, rolníka z Dětkovic. František Hanousek z Dětkovic věnoval dva špalíčky z 19. století (10.104, 10.105), a to z dědictví po své matce Františce Hanouskové. Obchodník Aug. Jiříček věnoval tři špalíčky. Mecenáš lidového umění Jan Zbořil z Lešan věnoval roku 1930 špalíček písní z 19. století (9.671). Soudní oficiant Ant. Snídal z Prostějova věnoval roku 1933 také špalíček světských a duchovních písní z 18.-19. století (11.145). Zajímavý zápis v knize je: „Špal. jarm. písniček duchovních“ - 19. století. Dar: „Zem. a univ. Knihovna v Brně r. 1933“ (11.146). Darem Karla Vymazala z roku 1936 získalo muzeum špalíček pěti duchovních písní z 19. století (13.579), krejčí Vlad. Pospíšil daroval špalíček 26 světských písní z 18. a 19. století (13.580). Zřízenec městského chudobince $\mathrm{Al}$. Holický věnoval v roce 1937 špalíček 53 jarmarečních písní českých i německých z druhé poloviny 19. století (14.809). V roce 1938 darovala M. Součková z Prostějova špalíček 30 náboženských modliteb českých a německých z 18. a 19. století (14.802). Špalíček 42 náboženských a světských písní z let 1768 1818 (14.804) daroval muzeu Radim Kment z Drozdovic, žák druhé třídy měšt'anské školy v Prostějově. Špalíček devíti nábožných písní (14.805) darovala paní Běhálková, celoživotní sběratelka lidového umění (především fotografií a krojů). Špalíček šesti jarmarečních písní (14.812) je darem dr. Jar. Mathona. Darem z roku 1943 od S. Boháčka z Prostějova je špalíček jarmarečních písní většinou tištěných v Litomyšli na počátku 19. století (17.189). J. Jančík Fachlehrer z Prostějova věnoval čtyři špalíčky duchovních a světských jarmarečních písní (17.192, 17.195, 17.196, 17.197). Další špalíček věnovali F. Dubový z Prostějova (17.194), Václav Londěra (17.199), J. Šíma z Prostějova (17.201), M. Červinková z Prostějova (17.203), František Bartošek - řídící učitel z Brna (17.920), prof. Vilém Otáhal starosta Prostějova - špalíček světských písniček vydaných v Chrudimi u Pospíšila z let 1857-1863 (8.127) a také dalších pět špalíčků $(8.128,8.129,8.130,8.131,8.162)$.

Raritou je dar z 11. ř́ijna 1965 jarmareční kramářské písně Když jsem šel z jarmarku z Prostějova, k níž nápěv složil sám dárce výtisku, Jan Poláček z Prostějova (277).

\section{Muzeum v Ivančicích (pobočka Muzea Brněnska)}

Sbírka písní v Muzeu v Ivančicích ${ }^{33}$ obsahuje nejen písně kramářské, ale i poutní modlitby. ${ }^{34}$ Většinu kramářských písní odborně popsala a vyčerpávající seznamy $\mathrm{k}$ této části akviziční činnosti muzea pořídila prof. Olga Uhrová. ${ }^{35}$

Často je v evidenčních kartách jako datum nabytí uveden rok 1941 bez bližší specifikace, zda se jednalo o dar, nebo koupi. Objevuje se tu totiž speciální fenomén - rodiny z Ivančic a blízkého okolí si své vzácné předměty v průběhu druhé světové války dočasně uschovávaly do muzea. Mnohdy se, bohužel pro jejich majitele (at' již z jakéhokoliv důvodu), stalo, že se tyto předměty posléze staly trvale součástí sbírky muzea. A to je i př́ípad konvolutů kramářských písní.

Právě z roku 1941 pochází špalíčky, jejichž původními majiteli byla rodina Košíčkova. Soubor sedmi poutních

\footnotetext{
${ }^{30}$ Sbírka Josefa Květoně je především unikátní numismatickou sbírkou.

${ }^{31}$ Státní okresní archiv Znojmo, fond Jihomoravské muzeum ve Znojmě, doklad Z/JMM, kart. Č. 15, inv. č. 972-992 (č. 17, č 19).

${ }^{32}$ Roku 1883 byl v Prostějově založen spolek Průmyslové jednoty, jehož členové chtěli oživit řemesla a živnosti ve městě. Z jeho aktivit vzniklo 14. srpna 1887 prostějovské muzeum umístěné v jedné místnosti dvorního traktu Waitova domu. V roce 1893 se v Prostějově konala Národopisná výstava - shromážděné předměty se staly základem muzejních sbírek, vznikla Muzejní a průmyslová jednota, která 25 . května 1894 otevřela v prostorách prostějovského zámku muzeum. Dne 17. záŕí 1905 se muzeum přestěhovalo do bývalé renesanční radnice.

${ }^{33}$ Muzeum v Ivančicích je jedno z nejstarších moravských regionálních muzeí. Podobně jako u jiných institucí obdobného typu stála na počátku jeho existence výzva ke shromažd’ování materiálů na Národopisnou výstavu českoslovanskou v Praze roku 1895 . Dne 6 . prosince 1892 byly schváleny stanovy Musejního spolku v Ivančicích. Sběratel lidových pohádek a pověstí a ivančický rodák Beneš Metod Kulda se stal prvním zakládajícím členem. Dne 10. června 1894 se konalo slavnostní otevření „,městského muzea v Ivančicích“. Hlavní osobností období počátků muzea byl všestranný Josef Vávra, ředitel měšt’anské školy. V roce 1938 předal Musejní spolek v Ivančicích své sbírky městu na pokyn Svazu československých muzeí. Období druhé světové války přečkalo muzeum bez velkých problémů. V roce 1965 bylo ivančické muzeum sloučeno s muzeem v Židlochovicích a stalo se součástí okresního muzea pro okres Brno-venkov (spolu s Podhoráckým muzeem v Tišnově, městským muzeem ve Šlapanicích a památným objektem Mohyla míru). Dnes toto muzeum nese název Muzeum Brněnska. 80 let muzea v Ivančicích 1894-1974 1974 , s. 3-7.

${ }^{34}$ Výčet modliteb v tomto článku záměrně neuvádím.

${ }^{35}$ Prof. Olga Uhrová, dcera zakladatele muzea Josefa Vávry, působila od roku 1962 jako ředitelka muzea. Dříve byla dlouholetou a velmi aktivní členkou Musejního spolku. Protože byla vybavena odbornou kvalifikací a zároveň byla dobře obeznámena s regionální problematikou a sbírkovým muzejním fondem, její nástup do muzea byl velmi prospěšný. 80 let muzea v Ivančicích 1894-1974 1974, s. 7.
} 
modliteb IC 232 je věnován sv. Anně (datována je pouze jedna $\mathrm{z}$ nich rokem 1808, tištěny byly v Jihlavě a Litomyšli).

Pravděpodobně i jistý úředník, pan Kropáček, si svůj velmi unikátní špalíček v černém látkovém obalu uschoval $\mathrm{V}$ roce 1944, tedy v průběhu druhé světové války, do muzea. Dnes je způsob nabytí tohoto předmětu pod inv. číslem IC 220 evidován jako „dar“. Špalíček obsahuje 13 rukou psaných písní (nedatovaných, duchovní témata se obracejí k Panně Marii a Ježíši Kristu, mezi světské patří například písně $O$ mrtvém milenci či Píseň pred Korunkou) a 17 tištěných písní, z nich je sedm světských - Nová píseň o Americe (V Olomouci: u Ant. Halousky, 1856) nebo Píseň kanonýra o Nanynce - zbytek písní je duchovních vztahovaných především k Panně Marii (Cellenské, Svatohorské).

Špalíček IC 217 původně patřil Marii Klorové (žijící asi v letech 1786-1866), muzeu ho darovala učitelka hudby Milada Malá z Ivančic na Hané. Ke špalíčku je přiložen podrobný strojopisný seznam všech 161 písní obsahující názvy, nápěvy, místa vydání, tiskaře či nakladatele včetně roků vydání. Ke konvolutu písní dárkyně přidala ručně psaný lístek s textem: „Sebrané písně od mé prababinky, Marie Klorové, vdově po c. k. lesním v Kraskově v Čechách u Seče ... 1866 v 80 roků stará.“ Z celkového počtu 161 položek z let 1795-1866 je 95 písní světských a 66 písní duchovních. Nejrozsáhlejším tématem duchovních písní jsou zpěvy věnovány Ježíši Kristu. Dále se písně obrací k Panně Marii, Jidáši Iškariotskému, sv. Máří Magdaléně, sv. Anně, sv. Františku Serafinskému, sv. Antonínu Paduánskému, sv. Janu Nepomuckému či sv. Kateřině. Písně pochází ze Skalice (Fr. X. Škarnicla a synů), z Litomyšle (Václav Tureček), ze Znojma (Martin Hofmann), z Chrudimi (Jozef Košina), z Prahy (Jozefa Elenwangerová, František Šota), z Pardubic, z Opavy a řada z nich byla vytištěna $v$ Těšíně. Mezi světskými motivy se objevují samozřejmě tradiční témata, ale najdeme mezi nimi i např́iklad následující: Nová píseň o náramném sněhu v Ruské zemi, a o strašném ohni v Moskvě, kdežto nynějšiho roku 1838 tak mnoho sněhu napadlo (bez místa vydání, nedatováno), Píseň nová o prehrozném neštěstí na hlavní město Pešt v Uherské zemi a Budin uvaleného (Vytištěná v Skalici, nedatováno), Nová píseñ aneb truchlivý přiběh, který se stal bliž města Jaroměre (v Praze, nedatováno), Žalostná píseň o hrozném krveprolití $v$ Praze v žalostných a smutných dnech 11. až do 16. června 1848 (v Praze, 1848), Truchlivý přiběh, který se stal v Bavořich, s této písně vyrozumí se (v Skalici, nedatováno) nebo Pravdivá píseň o řmeslu tkalcovském (bez místa vydání, nedatováno). Objevují se tu také dvě písně připsané autorům: Nová písen̆ mládencům a pannám pro obveselení mysle na světlo vydaná. Složená od Matesa Fripa - v Lovkově je zrozený (bez místa vydání, nedatováno) a Nová písen̆ mládencưm a pannám k spěvu vydaná a odemne A. Ch. sepsaná (pozn. kurátora: snad Antonín Chloupek).

Špalíček IC 238/1-8 obsahuje osm položek, především modliteb k sv. Janu Nepomuckému z let 1780-1856 vydaných v Praze nebo v Brně. Součástí jsou i dvě položky v němčině: Gebet zu Gott in rmuth und Bedrängnis, durch die Jürbitte des heiligen Johann von Nepomuk Trost und hilfe zu erlangen (bez místa vydání, nedatováno) a Ecclesia B. Virg. Marie Evancziensis (V Brně, 1780).
Darem M. Peichlové z roku 1963 získalo Muzeum v Ivančicích osm kramářských duchovních písní uložených pod inv. číslem IC 227 oslavujících Pannu Marii, Ježíše Krista a sv. Jana Nepomuckého, tišsěné ve Znojmě, Př́ibrami, Litomyšli a ve Skalici (F. X. Škarnicla a synů), datace je pouze ve dvou prŕpadech - 1859 a 1866.

Malý volný špalíček 15 duchovních písní pod číslem IC 224 patřil Jos. Kaplerové. Písně se obrací k Ježíši Kristu, Panně Marii, Janu Nepomuckému, sv. Václavu či sv. Anně a pochází z Kutné Hory, z Pardubic, Jindřichova Hradce nebo z Litomyšle (od Josefiny Bergerové), datovány 1804 a 1805.

Dva špalíčky původně patřily příznivkyni Muzea v Ivančicích, Andělce Muzikářové. Muzeu je věnovala její dcera Cecílie Muzikářová v roce 1945. První špalíček IC 222, v papírovém obalu, obsahuje 34 písní, většina je duchovních a věnovaných Panně Marii (Hostinské, Křtinské, Sedmibolestné, Svatohorské), Ježíši Kristu a sv. Barboře. Jsou z časového rozmezí 1848-1873 a pocházejí ze Znojma (M. Hofmann, M. F. Lenk), z Jihlavy, Brna, Chrudimi (S. Pospíšil), z Olomouce (A. Halouska), ze Skalice (u Škarnicla synů) nebo z Litomyšle (Josefiny Bergerové). Druhý špalíček, v sametovém odřeném obalu (inv. číslo IC 221), obsahuje 29 písní, většina je opět s duchovním tématem - Panna Marie (Hostynská, Vranovská), Ježíš Kristus, sv. Anna, sv. Máŕí Magdaléna, sv. Josef a sv. Roch. Mezi světskými náměty se objevují Nová píseň o pravdivém zázraku (ve francouzské zemi 1849) (V Skalici u Škarnicla synů, 1860), Nová píseň o hrozné povodni u města Vidně v roku 1830 (bez místa vydání, nedatováno), Žalostná písen o jednom Maylandském malirri (bez místa vydání, nedatováno), Pravdivá píseň o turecké ukrutnosti (bez místa vydání, nedatováno) nebo Nová píseň o strašné vojně v uherské krajině (Znojmo - M. Hofmann, nedatováno).

Špalíček s inv. číslem IC 223 získalo muzeum 4. 12.1962 darem od ivančické fary prostřednictvím P. Jos. Ducháčka. Špalíček obsahuje 33 kramářských písní, 21 duchovních písní k Panně Marii, Ježíši Kristu, sv. Janu Nepomuckému, sv. Anně a 12 světských písní. Zajímavé jsou Píseň pravdivá o jednom zázraku, který se stal v štipském chrámu (1835) nebo Pravdivý zázrak o Maně, která s nebe v sleskej krajině pršela (V Praze, 1847).

Způsob nabytí menšího špalíčku kramářských písní v kůži vázaného s inv. číslem IC 219 není znám. Obsahuje jednu píseň světskou Př́kladná píseň o dvanácterých nevděčných dítkách (bez místa vydání, nedatováno) a 49 písní duchovních z let 1812-1853 vydaných ve Skalici, v Jihlavě, Kutné Hoře, v Litomyšli (Václav Tureček) či ve Znojmě (Martin Hofmann). V písních je oslavována především Panna Marie (Cellenská, Kunvaldská, Krrtinská, Premonstrátská, Sašínská, Svatohorská, Svatokopecká, Tálská, Vranovská), dále Ježíš Kristus, sv. Anna, sv. Jan Nepomucký, sv. Josef či sv. Máŕí Magdaléna.

Stejně tak není znám způsob nabytí malého špalíčku osmi světských kramářských písní s inv. číslem IC 226. Obsahuje písně z let cca 1833-1858 pocházející z Prahy, Olomouce, Skalice (Fr. X. Škarnicla), Znojma (M. F. Lenk) nebo z Chrudimi (u vdovy Frant. Košinovy). Kromě dramatických přiběhů o vraždách a ,mordech“ obsahuje i položku Nová píseň pro zasmání. Sedlské námluvy (Znojmo: M. F. Lenk, 1858). 
O tom, jakým způsobem se do muzea dostal špalíček 82 duchovních písní neznámého sběratele v koženém obalu, také neexistují žádné záznamy. Dle způsobu opotřebení se dá usuzovat, že byl v minulosti velmi často využíván. Většina písní pochází z druhé poloviny 18. století - první poloviny 19. století, pocházejí z Uherské Skalice, Litomyšle, Jindřichova Hradce, Kutné Hory (u Jana Rokosa, u Karla Samma) nebo z Písku. Zpěváci se obrací k Panně Marii (Cellenské, Svatohorské, Bechynské, Svatoduchské, Besednické), Ježíši Kristu, sv. Máří Magdaléně, sv. Anně, sv. Kateřině, sv. Václavu, sv. Benediktu nebo sv. Ivanovi.

Původ neznáme ani u špalíčku s inv. číslem IC 225 v látkovém obalu obsahujícího 15 písní (11 světských k sv. Anně, sv. Janu Nepomuckému nebo k Panně Marii Staroboleslavské; čtyřri duchovní) z doby kolem poloviny 19. století. Pod totožným inv. číslem je evidován samostatný tisk vydaný v 90. letech 19. století tiskem A. Jahody v Ivančicích s názvem Ženci a žnečky před sochou Panny Marie, který napsal O. Sadovský a v hudbu uvedl Fr. Neumann).

Špalíček s inv. číslem IC 229 obsahující 20 především mariánských kramářských písní z poloviny 19. století také nemá uvedeného konkrétního dárce, ale můžeme v něm najít razítko Musejního spolku v Ivančicích.

Neznámá je i cesta do muzea obsahově velmi zajímavého špalíčku s inv. číslem IC 233. Obsahuje v podstatně větší míře písně duchovní, objevují se tu však jména svatých, kteří nejsou $\mathrm{v}$ kramářských písních zmiňováni př́liš často - sv. Rozálie, sv. Jenovéfy, sv. Barbory, sv. Floriána či sv. Františka Paulanského. Mezi světskými motivy se objevují texty (je otázkou, zda je řadit mezi kramářské písně): Pozváni všech katolikio ku modlitbám smírným na den 9. června 1889 s prosbou, aby pozváni toto všude rozšiřováno bylo (Ve Vídni), Památka ze sv. misie nebo Hlas missionářu (V Jindřichově Hradci). Písně jsou z let 1781-1863, tištěny byly ve Vídni, v Chrudimi, v Praze, v Brně a v Jindřichově Hradci.

Ani u špalíčku s inv. číslem IC 246 původního majitele neznáme. Obsahuje písně světské i duchovní z let 18531868 tištěné v Olomouci, v Praze, ve Skalici u Škarnicla synů, v Jihlavě u Jana Rippera nebo v Litomyšli u Antonína Augusty či Josefiny Bergerové. Některé písně jsou velmi poškozené, části listů vytrhané.

\section{Muzeum ve Šlapanicích (pobočka Muzea Brněnska)}

Sbírka kramářských písní v Muzeu ve Šlapanicích ${ }^{36}$ je velice skromná, obsahuje pouhé dva špalíčky, a je evidentní, že na rozdíl od jiných muzeí nebyl v historii šlapanického muzea zaměstnanec, který by se intenzivněji věnoval sběru tohoto artefaktu.

Špalíček šesti kramářských písní (č. inv. Hk232/1-6, velikost $16 \times 10,5 \mathrm{~cm}$, ze starého muzejního sběru - není bližší záznam o původu) je mezi špalíčky poněkud raritním kouskem. Obsahuje písně z let 1859-1866, z nichž čtyři mají záznam o autorství jednotlivých světských písní. Dovoluji si tu tedy uvést jejich kompletní seznam: Bartl, Prokop: Piseň česká krev která vylita byla mezi vojskem rakouským a pruským roku 1866 (Nový Bydžov: tiskem K. Kastránka), Haiß, František: Kratochvilná píseň o masopustní rekraci (Praha: tisk Jan Spurný, 1859), Žal cís. král. vojska po Radeckým. Složil slepý voják dle nápěvu Horo, horo vysoká si (Jičín: tisk Kastránek), Tuma, Frant.: Pravdivý př́běh který se jest v skutku vykonal. (Praha: tiskem Jana Spurného, 1862), Truchlivá píseň o jednom vojinu který sobě střelnou ránou život odňal (Mladá Boleslav: tiskem J. Zwikl, 1864) a Ter, Josef: Nářek zamilovaného (V Chrudimi: tiskem S. Pospíšil, 1862). ${ }^{37}$

Špalíček Hk177 o velikosti $11 \times 10 \mathrm{~cm}$ je dle prrírůstkové knihy darem Anny Hostové (v evidenční kartě je uveden jako předchozí majitel úřad Modřice). Obsahuje 30 kramářských písní z let 1779-1857, převážná většina $\mathrm{z}$ nich přináší tematiku duchovní, písně jsou věnovány Ježíši Kristu, Panně Marii (Sasínské, Vranovské, Cellenské), sv. Josefu, sv. Anně, sv. Máří Magdaléně nebo mučednici Filoméně. Pouze dvě písně se věnují světské tematice, z nichž jedna je Historická piseň o dvou židovských dětech (bez místa vydání, nedatováno). Pocházejí ze Skalice, Litomyšle (Václ. Tureček), Olomouce (A. Halouska), u mnohých místo vydání není uvedeno. ${ }^{38}$

\section{Závěr}

Podrobnějším vhledem do specifických sbírek jednotlivých institucí bylo možné přiblížit cesty jednotlivin kramářských písní a špalíčků do moravských muzeí a knihoven. Cílem prríspěvku nebylo podat vyčerpávající a přesný popis sbírek, motivací bylo spíše rekonstruovat jejich vývoj, způsob včlenění do muzejních sbírek a knihovních fondů, jejich uložení a kvalitu zpracování záznamů o nich. Zajímavé bylo i zjištovat, jak pevné místo mají tyto typy sbírek v rámci dané instituce a zda jsou předmětem hlubšího zájmu kurátorů a knihovníků, kteří o ně pečují. Z bližšího pohledu na historii vývoje jednotlivých sbírek a fondů vyplývá jednoznačné poznání - ty nejpočetnější a nejhodnotnější soubory a celky vznikaly tam, kde byl

\footnotetext{
${ }^{36}$ V roce 1889 byl založen Musejní spolek ve Šlapanicích. U jeho zrodu stáli učitel Josef Jarolím a kaplan Tomáš Babica. Nejen díky aktivitám těchto dvou mužů byl následně ve Šlapanicích roku 1893 založen Národopisný odbor pro Šlapanice a okolí, který sdružoval asi 40 členů především z měšt’anských rodin a z řad intelektuálů. Úkolem odboru bylo shromažd’ování exponátů a dalšího materiálu pro národopisnou výstavu v Praze (konanou 1895). Následně na podzim 1931 vznikl Spolek pro okrašlování a ochranu domoviny, který roku 1933 uspořádal v budově měšt’anské školy výstavku. Jeho členové se rozhodli, že vytvoří v rámci spolku čtyři sekce - zahrádkářskou, ovocnářskou, okrašlovací a zalesňovací a hlavně muzejní. Muzejní odbor uspořádal přednáśku ředitele národopisného odboru Zemského muzea v Brně dr. Pospíšila. Dne 18. února 1934 následovala výzva směrem k veřejnosti, na niž reagovali dárci budoucích muzejních exponátů (např. maliř Alois Kalvoda věnoval dva své obrazy a velkou uměleckou vázu). Věnováno či zapůjčeno bylo 427 předmětů. Vlastivědné museum ve Šlapanicích bylo slavnostně otevřeno 12. srpna 1934. Nejdříve sídlilo ve třech vypůjčených místnostech na Masarykově náměstí čp. 100 v domě MUDr. Pollacha. V období druhé světové války byly muzejní sbírky uloženy v bývalém obchodě Karla Velana v Nádražní ulici č. 449 v domě manželů Bílkových. Roku 1949 se muzeum přestěhovalo do budovy scholasterie čp. 104/18, kde sídlí dodnes. Roku 1965 se muzeum ve Šlapanicích stalo pobočkou muzea v Ivančicích, kde sídlilo vedení Okresního muzea Brno-venkov - dnešního Muzea Brněnska. KOPECKÝ 2004, s. 71-82.

${ }^{37}$ Evidenční karta inv. č. Hk232/1-6, Muzeum Brněnska - Muzeum ve Šlapanicích.

${ }^{38}$ Evidenční karta inv. č. Hk177, Muzeum Brněnska - Muzeum ve Šlapanicích.
} 


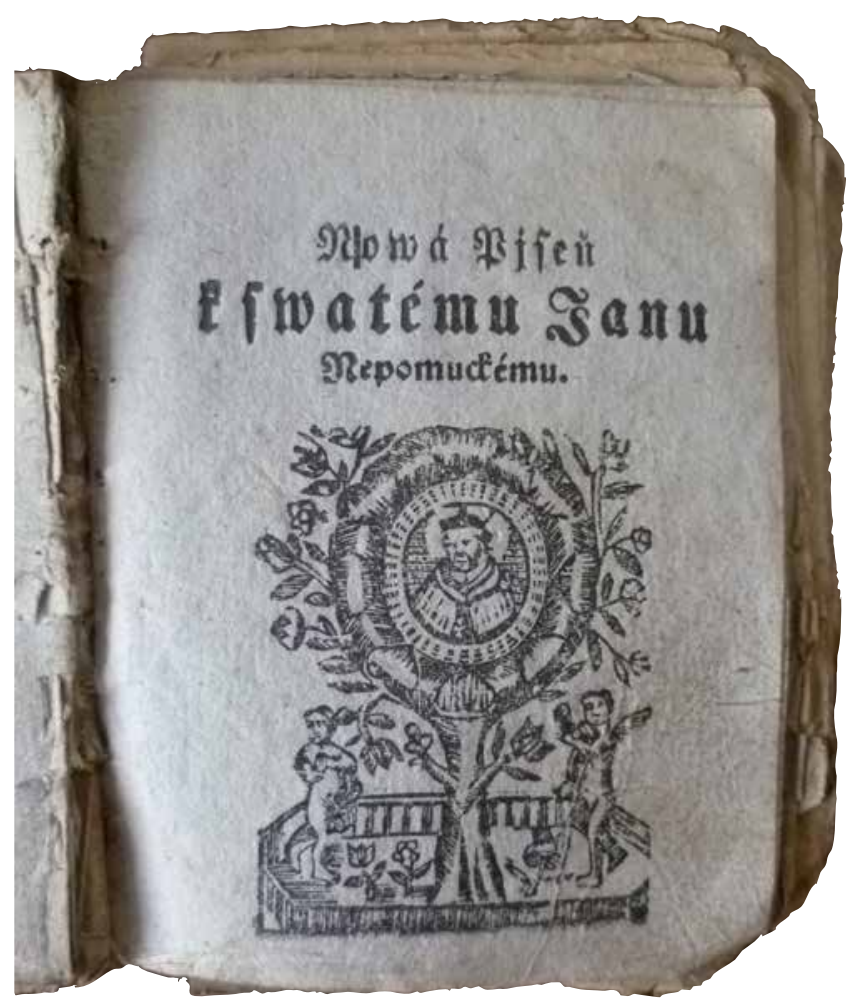

Obr. 3. Špalíček kramářských písní inv. číslo IC 246. Nová píseň k svatému Janu Nepomuckému. (Muzeum Brněnska - Muzeum v Ivančicích).

daný kurátor či knihovník odpovědným správcem, odborníkem na danou tematiku s osobní angažovaností v tomto tématu. Mnohdy bylo získání jednotlivých pozoruhodných celků podmíněno dobrou znalostí kramářských písní jednotlivce, jeho osobní vazbou ke sběratelům a vlastníkům unikátních soukromých sbírek a snahou získat tyto sbírky do institucí, které kramářské písně odborně ošetří, zpř́ístupní badatelům, ale hlavně zachovají prř́štím generacím. Ne každé muzeum se na sběr kramářských písní zaměřovalo. Samožrejmě můžeme otázku, jak se písně do jednotlivých institucí dostávaly, shrnout do jednoduché informace - darem, sběrem či koupí. Při bližším a hlubším pohledu však zjistíme, že se za těmito třemi slovy mohou skrývat rozličné příběhy či nuance. Př́kladem může být velký, celoplošný sběr dr. Pavlištíka na Zlínsku, ukrývání špalíčků v Muzeu v Ivančicích v průběhu druhé světové války nebo pravděpodobný zisk pozůstalostí místních tiskařů ve Znojmě.

\section{Prameny:}

Fond Staré tisky (podskupina Kramářské písně) Moravské zemské knihovny v Brně.

Fond Tisky (podskupina Kramářské tisky) Muzea jihovýchodní Moravy ve Zlíně.

Fond Dějiny školství (podskupina Kramářské tisky) Muzea Komenského v Přerově.

Knihovní fond Muzea Brněnska - Muzea v Ivančicích.

Knihovní fond (podskupina Zábavní literatura) Muzea Brněnska - Muzea ve Šlapanicích.

Knihovní fond Muzea a galerie v Prostějově.

Knihovní fond Vědecké knihovny v Olomouci.
Sbírka kramářských písní Jihomoravského muzea ve Znojmě. Sbírka kramářských písní ve Slováckém muzeu v Uherském Hradišti.

Státní okresní archiv Znojmo, fond Jihomoravské muzeum ve Znojmě.

\section{Literatura:}

ATWERI 2008: ATWERI, Jiří. Historie Jihomoravského muzea ve Znojmě. In: Jihomoravské muzeum ve Znojmě. Muzeum - Brána k poznání. Sborník ke 130. výročí založení. Znojmo: Jihomoravské muzeum ve Znojmě, 2008.

ČERNÝ 2010: ČERNÝ, Norman. Kramářské pisně ve Slováckém muzeu v Uherském Hradišti. Olomouc, 2010. Bakalářská práce. Univerzita Palackého v Olomouci. Filozofická fakulta.

FROLEC 2000: FROLEC, Ivo (ed.). Slovácké muzeum Uherské Hradiště. Uherské Hradiště: Slovácké muzeum, 2000.

HÝBL 2001: HÝBL, František. Muzeum Komenského v Přerově. Přrerov: Muzeum Komenského v Přerově, 2001.

KOPECKÝ 2004: KOPECKÝ, Josef. 70 let Muzea ve Šlapanicích. In: Sborník Muzea Brněnska. Předklášteří: Muzeum Brněnska, 2004.

PLÁNKA 2003: PLÁNKA, Ivan (ed.). Muzeum jihovýchodní Moravy ve Zlíně. Zlín: Muzeum jihovýchodní Moravy ve Zlíně, 2003.

PRUDKÁ 2017: PRUDKÁ, Alena. Jaroslav Žíla-Lipjan národopisný pracovník. Acta Musealia XV, 2017, č. 1-2, s. $246-250$.

PRUDKÁ 2018: PRUDKÁ, Alena. Muzejní stopa Karla Pavlištíka. Acta Musealia XVI, 2018, č. 1-2, s. 206-210.

80 let muzea v Ivančicich 1894-1974 1974: 80 let muzea v Ivančicich 1894-1974. Ivančice: Okresní muzeum Brnovenkov v Ivančicích, 1974, s. 3-7.

\section{Elektronické zdroje:}

iDNES.cz 2021, [online]: iDNES.cz / Zpravodajství / Zlín. [online] [Cit. 22. 5. 2021]. Dostupné z: https: www.idnes.cz/ zlin/zpravy/zlin-muzeum-objev-kniha-dar-svazek-kramarske-pisne.A210317_599367_zlin-zpravy_hoo ČTENÍ Z PÍSKU 2021, [online]: ČTENÍ Z PÍSKU [online]. [Cit. 30. 5. 2021.] Dostupné z: http://www.ctenizpisku.cz/ cteni autori/kremen-frantisek

Salvatoriáni 2021, [online]: Salvatoriáni [online]. [Cit. 30. 5. 2021.] Dostupné z: http://www.schnablova.net/ Sakralni\%20architektura/Specialni/Kategorie/salvatoriani. htm.

Ř́mskokatolická farnost Lichnov a Vlčovice 2021, [online]: Ř́mskokatolická farnost Lichnov a Vlčovice [online]. [Cit. 30. 5. 2021]. Dostupné z: https://www.farnostlichnov. cz/lichnov-farnost/

\section{| Romana Macháčková}

Moravská zemská knihovna v Brně Kounicova 65a

60187 Brno 